REVISTA ANDALUZA DE ANTROPOLOGÍA.

NÚMERO 6: LOS MOVIMIENTOS SOCIALES Y LA CONSTESTACIÓN AL ORDEN GLOBAL.

MARZO DE 2014

ISSN 2174-6796

[pp. 31-60]

http://dx.doi.org/10.12795/RAA.2014.i06.02

Fecha de Recepción: 24-01-2014

Fecha de Aceptación: 03-03-2014

\title{
TRAS LAS HUELLAS DEL MAU MAU: MEMORIA, AMNESIA Y REINVIDICACION DE JUSTICIA
}

\section{Paz Moreno Feliu \\ Universidad Nacional de Educación a Distancia (UNED)}

\section{Resumen.}

En las últimas décadas muchos antropólogos han utilizado conceptos como memoria, sufrimiento social, guerras coloniales o genocidio. Sin embargo, estos problemáticos conceptos solo cobran sentido cuando están imbricados en relaciones sociales específicas. La revuelta Mau Mau (Kenia colonial, 1952-1959) se ha analizado como una rebelión campesina, como un movimiento nacionalista anticolonial, como una guerra civil entre Kikuyu o como una frontera ideológica entre la "civilización europea" -una civilización entre alambradas- y "el salvajismo africano" - con sus ceremonias de circuncisión y juramentos.

A partir de nuevos datos etnográficos, históricos y judiciales este artículo relaciona el régimen de terror impuesto por el Estado de Excepción (castigo de civiles, violencia ejercida contra sus cuerpos y creación de campos de reclusión) con la ausencia postcolonial de políticas de la memoria y la amnesia judicial.

\section{Palabras clave.}

Memoria, régimen de terror, género, sufrimiento social, moralidades, genocidio.

\section{Abstract.}

Memory, social suffering, colonial wars and genocide are concepts which have been widely used by anthropologists in the last decades. However these problematic concepts are embedded in specific social relations. Mau Mau Uprising (colonial Kenyia, 1952-1959) has been analysed as a peasant revolt, as a Kenyian nationalist and anticolonial rebellion, as a Kikuyu civil war and as an ideological frontier between "European civilization" -a wired civilization- and "African savagery" -circumcision and oathing ceremonies.

Using new ethnographic, historical and judicial data this paper relates the regime of 
terror under the British State of Emergency (punishment of civilians, violence against their bodies, detention camps, Kikuyu civil war) to postcolonial lack of memory policies and judicial amnesia.

\section{Keywords}

Memory, regime of terror, gender, social suffering, moralities, genocide.

\section{INTRODUCCIÓN}

La obra clásica de F. Yates, El Arte de la Memoria, parecería a primera vista estar en las antípodas del interés suscitado en varias disciplinas, desde los años 80 del pasado siglo, por unos estudios sobre la memoria, cuya frecuente adjetivación -colectiva, histórica, individual, cultural o social- nos indica la falta de acuerdo entre distintos especialistas sobre los distintos significados del término, sobre sus campos de aplicación y en última instancia, sobre su estatuto epistemológico.

Decíamos en las antípodas porque Yates dedicó su investigación a cómo el mundo de los clásicos grecolatinos -tan ligado a la oralidad- había resuelto el problema de memorizar, es decir, qué técnicas y prácticas configuraban el palacio de la memoria en cuyos lugares imaginarios se colocaban conceptos e ideas verbales que les permitían registrar lo que se quería recordar; mientras que nuestras sociedades se plantean la memoria como problema de estudio, cuando cuentan con un sinfín de medios técnicos para guardar y reproducir el recuerdo, bien sea conservando las imágenes o las voces mismas, bien mediante una elaboración escrita posterior.

Sin embargo, a pesar de nuestra sobredimensión tecnológica, Yates, al indicarnos los primeros pasos del arte de la memoria recurre a su relación con ciertos loci externos, que le permiten, desde la primera página de su libro, situarla en una dimensión social y cultural ligada conceptualmente al espacio ${ }^{1}$.

1. La perspectiva clásica asociaba la memoria con una dimensión arquitectónica del espacio, que al permitir ordenar un conjunto de elementos, posibilita el recuerdo. Yates (1974) comienza su libro refiriendo el origen mitológico del arte y su ligazón con los lugares: "En un banquete que daba un noble de Tesalia llamado Scopas, el poeta Simónides de Ceos cantó un poema lírico en honor de su huésped, en el que incluía un pasaje en honor de Castor y Pólux. Scopas dijo mezquinamente al poeta que él solo le pagaría la mitad de la cantidad acordada y que debería obtener el resto de los dioses gemelos a quienes había dedicado la mitad del poema. Poco después, Simónides recibió el mensaje de que dos jóvenes le estaban esperando fuera y querían verle. Se levantó del banquete y salió al exterior, pero no logró hallar a nadie. Durante su ausencia se desplomó el tejado de la sala aplastando y dejando, bajo las ruinas, muertos a Scopas y a todos los invitados; tan destrozados quedaron los cadáveres que los parientes que llegaron a recogerlos para su entierro fueron incapaces de identificarlos. Pero Simónides recordaba los lugares en los que habían estado sentados a la mesa y fue, por ello, capaz de indicar a los parientes cuáles eran sus muertos". 
Pero resulta importante no pasar por alto que en el texto de Yates, por alejado que parezca de nuestras técnicas de registro actuales, sea precisamente la memoria la que permite, tras una catástrofe, reconocer a los muertos, restituirles su identidad y que sus familias les dedicasen las ceremonias específicas con las que los antiguos helenos honraban a sus difuntos: la ligazón que establece el mito de origen entre memoria, espacio, identidad y destrucción persiste en muchos de los estudios actuales sobre la memoria.

No hace mucho, en la que sería una de sus últimas publicaciones, el clasicista Jean Pierre Vernant (2008) reflexionaba sobre la memoria, no solo como helenista acostumbrado a explicar las formulas con que los aedos aprendían la Odisea, sino también cómo la memoria de su experiencia de resistente contra el gobierno de Vichy difería de los relatos en los que el "enfoque histórico" daba cuenta de esos mismos sucesos en los que había participado. Vernant al distinguir diferentes planos evitaba la frustración que mostraban muchos de sus viejos compañeros de la Resistencia que no reconocían en la narrativa profesional los acontecimientos que habían vivido, porque "los historiadores no tienen la intención de revivir los acontecimientos pasados, de resucitarlos en su carne y en su sangre para que los testigos se reconozcan a sí mismos y se sientan, otra vez, conmovidos y emocionados" (Vernant, 2008: 30).

La cuestión tal y como la plantea Vernant es que las memorias individuales de los actores, la memoria social del grupo -presente en las conmemoraciones institucionales, pero también en películas o en fuentes orales o escritas- y la memoria histórica, centrada en la obra de historiadores profesionales que buscan narrar la verdad de un acontecimiento histórico, generan memorias diferentes, ninguna de las cuales es inmutable: "Hay, pues, una historia de la memoria. Pero más allá de que esta sea individual, social o histórica siempre es una construcción compleja y no una coincidencia inmediata con un pasado concluido" (2008: 33).

La reflexión de Vernant es importante porque, frente a quienes acaban por reificar la memoria, su perspectiva de que las memorias son plurales y cambiantes nos permite partir de que la existencia de discrepancias es una parte integrante de la dinámica en que se insertan en las sociedades las distintas historias y políticas de la memoria. Así, por ejemplo, desde el punto de vista institucional, interpretaremos que la inclusión y la exclusión de unos elementos y grupos frente a otros forma parte de los procesos políticos en que se articulan qué aspectos del pasado son significativos en el presente y para quién. En otras palabras, daremos entrada a una problemática que puede ser conflictiva y contestada en función de las representaciones de las distintas memorias existentes y en cómo y en qué terrenos los distintos actores discrepan sobre lo que desde el poder se pretende recordar y olvidar. Las disputas sobre memorias contrapuestas siempre tienen orígenes históricos específicos, como también lo son los mecanismos de instrumentalización política del pasado que utilicen los grupos en el poder y que pueden originar reivindicaciones de justicia por parte de aquellos grupos cuyo sufrimiento social 
se ha excluido de la memoria: este tipo de exclusión no ha de entenderse meramente en términos políticos, sino como una puesta en cuestión de la propia moralidad social.

Del mismo modo, la dinámica entre las distintas memorias sitúa en el primer plano tanto la problemática relación entre la historia oficial, la historia de las distintas memorias y el poder (Olick y Robbins, 1998), como la persistencia de narrativas distintas a las oficiales que cuestionen la manipulación política o histórica que puede hacerse o se ha hecho del pasado.

Como es evidente no todos los acontecimientos del pasado sacan a la luz pública la compleja articulación entre memoria y moralidad. Nos referimos a situaciones en las que se han perpetrado crímenes extraordinarios cometidos o consentidos por el propio Estado -como puedan ser los asesinatos de civiles y las represalias contra sindicalistas o afiliados a partidos políticos de izquierdas tras el Golpe de Estado de Franco, crímenes similares ocurridos durante la guerra civil griega (Mamoulaki, 2012), la persecución, tortura y asesinato de los acusados de pertenecer al Mau Mau durante el estado de excepción impuesto en Kenia desde finales de los años 50 por parte de las autoridades coloniales o un sin número de crímenes silenciados cometidos en diversos etnocidios o genocidios.

En estos casos, independientemente del tiempo transcurrido, las políticas de amnesia impiden a los grupos sufridores olvidar las injusticias padecidas. Es en estas situaciones donde la confrontación de memorias se muestra como el único camino a partir del cual se pueden obtener reparaciones. Kleimman, Das y Lock (1997) en la introducción a su imprescindible recopilación de artículos sobre el sufrimiento social señalan que "las representaciones culturales del sufrimiento lo moldean como una forma de experiencia social" (1997: xii), que se aprende, se comparte o que lleva a contestar las políticas de la memoria institucional que impiden que la justicia se aplique a las víctimas. Como dicen en Kenia con un refrán muy significativo, "Quien ha sido derrotado con una fuerza injusta, siempre regresará; quien ha sido tratado justamente, no volverá".

Los pormenores del caso Mau Mau no se habían conocido en su totalidad hasta que las recientes investigaciones académicas (por ejemplo las de Elkins y Anderson) cuestionasen las interpretaciones históricas coloniales y renovasen el interés por la memoria de las víctimas. Ambos historiadores fueron también testigos en la larga batalla legal que finalizó en junio de 2013 con la promesa de reparar los daños causados a unos 5000 supervivientes.

Los reportajes aparecidos en la prensa británica sobre el contenido de archivos secretos, sacados a la luz durante el juicio, han convertido el pasado colonial del antiguo paraíso 
de Karen Blixen en la Argelia del Imperio Británico². Sin embargo, como en tantos otros casos similares, han tenido que pasar más de 60 años para que alguna de las múltiples instituciones que administran la justicia, repartiera una pequeña dosis a quienes habían sufrido más de diez años de violencia política y sexual.

La cuestión que vamos a analizar, integrando los varios tipos y niveles de memoria que han aparecido en las monografías y en los documentos judiciales, es la siguiente. En sus orígenes, en los años 50 del pasado siglo, el Mau Mau parece surgir como un grupo reivindicativo -su lema era "tierra y libertad"- de los agricultores Kikuyu a quienes las autoridades británicas habían requisado sus tierras para que los colonos europeos pudiesen establecer en ellas sus granjas. Tras sus primeras acciones -que indicaban también un conflicto interno, próximo a una guerra civil, entre las élites y la mayoría Kikuyu- la represión colonial acabaría por radicalizar los objetivos del Mau Mau y convertirlo en un movimiento casi nacionalista -aunque nunca logró la adhesión generalizada de otros pueblos que habitaban lo que después sería Kenia- en busca de la independencia.

Las autoridades imperiales presentaron ${ }^{3}$ la guerra contra el Mau Mau como si se tratara de una frontera imaginada entre la "civilización" de los colonos blancos y el "salvajismo" de los africanos. Siguiendo esta metáfora, el "salvajismo" africano se reflejaba tanto en la defensa de la mutilación genital femenina, como en el batuni, juramento mediante el que los hombres y las mujeres Kikuyu se adherían al Mau Mau y, según se manifiesta en su memoria, prometían matar a todo colono blanco. La "civilización" de las autoridades coloniales, se expresaría en la promulgación del Estado de Excepción, que les permitió recluir bajo alambradas en la selva y en las aldeas a la población de varios distritos Kikuyu.

\section{KENIA COLONIAL: GOBIERNO INDIRECTO, ORDEN TRIBAL Y REBELIÓN MAU MAU}

Como recientemente han señalado varios autores, el colonialismo no fue un proceso genérico, independiente de las realidades históricas, sociales, económicas, políticas y culturales de los distintos lugares y de la forma de colonizar de las distintas metrópolis (Cooper, 2005). A pesar de la existencia de matices y variaciones menores, podemos aislar, a modo de tipos ideales, dos grandes trayectorias que marcan dos clases de

\footnotetext{
2. El diario británico The Guardian ha agrupado en un dossier, de lectura imprescindible para cualquier persona interesada, los artículos de Ian Cobain sobre las demandas judiciales presentadas por algunos presos sometidos a torturas, violaciones, castraciones y trabajos forzados. Este mismo año se ha condenado por primera vez al Estado Británico. En muchos otros tribunales internacionales la guerra contra el Mau Mau se está replanteando como un caso de genocidio.

3. En esta interpretación y en las políticas de atracción de aliados Kikuyu contrarios al Mau Mau habría sido muy relevante el papel del palentólogo L.Leakey, hijo de unos misioneros y que se consideraba a sí mismo un "Kikuyu blanco", lengua que hablaba perfectamente.
} 
relaciones diferentes: la de aquellos lugares en los que se habían asentado grupos estables de colonos procedentes de la metrópolis y la de los países en los que los colonos eran o inexistentes o no se habían agrupado.

La existencia de colonos se corresponde con el tipo de colonización que el sociólogo M. Mann (2009) denomina imperialismo ecológico, esto es, aquel que se dio en ciertas zonas geográficas que, por contar con condiciones medioambientales similares a las regiones pobladas por europeos, permitían a personas, semillas y animales adaptarse en ese entorno. Ciertas regiones de Kenia, al igual que la antigua Rhodesia (Zimbabwe), Namibia o Sudáfrica, contaron con una población significativa y estable de colonos blancos, que explotaban tanto pequeñas propiedades como extensas granjas bien comunicadas entre sí, en el caso de Kenia, por la línea de ferrocarril que unía la costa con el lago Victoria ${ }^{4}$.

Los colonos blancos no constituían un grupo homogéneo, porque, en su contexto africano, reproducían las divisiones de clase que regían en la sociedad victoriana. Había pequeños granjeros ingleses, cuyo número se incrementaría después de la I Guerra Mundial, por la generosa política de reparto de tierras que el gobierno británico había potenciado para que se estableciesen en Kenia los militares desmovilizados. A este grupo, habría que añadir un grupo, relativamente numeroso, de emigrantes blancos -afrikaners- procedentes de Sudáfrica y un número variable de pequeños artesanos y negociantes asiáticos.

Frente a las pequeñas granjas y pequeños comerciantes, había un grupo de grandes explotaciones en las fértiles altiplanicies de Kenia Central, adquiridas por conocidas familias aristocráticas para instalar allí a los hijos que no heredaban el mayorazgo. La forma de vida de estos aristócratas terratenientes, en gran parte descrita por Karen Blixen, transcurría en las grandes mansiones que se habían hecho construir, rodeados de objetos lujosos traídos de la metrópolis, mientras las condiciones coloniales les permitían jugar a ser grandes señores, atendidos por una multitud de criados domésticos a su servicio. Se distraían con la caza de grandes animales, las reuniones sociales en el

4. La importancia de esta distinción -presencia o ausencia de colonos- radica en su influencia en los procesos posteriores de descolonización. Como señala Mamdani, antropólogo especialista en este tipo de procesos: "En aquellos lugares donde la minoría de colonos disputaban el poder político a la mayoría nativa y al poder imperial -como ocurrió en Sudáfrica durante la guerra de los Boers, en Kenia durante el Mau Mau y en Zimbabwe tras la declaración unilateral de independencia- los nativos lograron la independencia estatal tras librar una lucha interna -siempre extraoficial y a menudo armada-. En donde no había colonos establecidos como grupo o sin reivindicar el poder político, el poder colonial tenía un mayor margen de maniobra para distinguir entre nacionalismo militante y moderado y -al enfrentarlosinstrumentar la independencia en consonancia con las nociones imperiales de la armonía de intereses en el África postcolonial. Estas dos trayectorias de la descolonización -una armada y otra no violenta- eran el resultado de distintos modos de colonización" (Mandani, 2001: 103). 
exclusivo Muthaiga Club de Nairobi, los enredos sentimentales cosmopolitas o las visitas de negocios, con parada en lujosos hoteles de la capital que disponían de unas exóticas prostitutas japonesas (White, 1990ª).

A pesar de que la falta de experiencia agrícola de los aristócratas hizo que la productividad -tanto de las plantaciones como de las granjas- siempre fuese muy baja, los distintos colonos blancos actuaban como un grupo de presión, como una fuerza política que pretendía desplazar a los africanos para lograr que las partes más fértiles de Kenia se transformasen en un exclusivo "país de blancos".

Legalmente, el gobierno colonial (Mamdani, 1996 y 2001) distinguía y gobernaba para dos cuerpos políticos, el de los colonos, un sistema político de ciudadanos que vivían bajo unos códigos legales que les reconocían derechos civiles, obligaciones y una administración de justicia y el tribal, un sistema político de súbditos, basado en un código de costumbres -según su reinterpretación/invención colonial- que regía la vida de los nativos. Esta doble dimensión es el punto de partida para comprender algunas de las cuestiones planteadas por el Mau Mau.

Ahora bien, el modelo social era mucho más complejo de lo que pudiera parecer a primera vista, porque ninguno de los dos bloques a los que se aplicaban las distintas racionalidades de gobierno era homogéneo, sino que cualquiera de ellos tenía numerosas divisiones internas, ya fuesen de clase, étnicas o de género. En otras palabras, el sistema real no constaba de una sociedad dividida en dos mitades como si fueran mundos apartes, uno de colonos y otro de nativos, sino que la Kenia colonial era una sociedad formada por un complejo entramado de diversas "tribus" africanas, como las denominaban las clasificaciones oficiales, que tenían intereses tan opuestos como suelen ser los de agricultores y pastores; una población de inmigrantes de origen asiático, granjeros afrikáners, colonos británicos originarios de clases trabajadoras, militares retirados, aristócratas, misioneros y funcionarios coloniales.

Los más de cuarenta pueblos nativos de Kenia habían sido divididos en "tribus", a cada una de las cuales los británicos le habían atribuido una especialización social que, en muchos casos, era consecuencia de la ideología racial de los europeos sobre las aptitudes de los africanos: según esta clasificación, los pastores Masai, tenían disposiciones para llegar a convertirse en guardias; los Kikuyu en granjeros; los Luo en profesores o los Kamba en burócratas.

Las propias políticas coloniales fomentaron, pues, una separación étnica y social, que no solo era ideológica: las autoridades habían dividido las tierras en que habitaban los distintos pueblos en "reservas tribales". De esta forma, lograron "reservar" las zonas más productivas y con mejor clima para las granjas de los colonos, al tiempo que evitaron -con esta máxima del "divide y vencerás"- que los distintos pueblos tuviesen proyectos 
políticos comunes 5 . De todos los grupos "tribales" de Kenia, los agricultores Kikuyu fueron quienes más sufrieron la colonización: les expropiaron sus tierras para que los blancos establecieran sus granjas en ellas, además de negárseles la posibilidad de cultivar en nuevos lugares. De este modo, hacia los años 30, la productividad de las tierras de las reservas empezó a decrecer, como consecuencia de la sobreexplotación causada por la presión demográfica. En la vida Kikuyu convertirse en adultos, tanto en hombres como en mujeres, exigía el acceso a la tierra y a sus cultivos: los hombres para pagar el precio de la novia; las mujeres para cultivar y abastecer a su familia.

La única solución que encontraron algunos Kikuyu fue la ocupación de tierras marginales de los colonos, quienes les permitían cultivarlas a cambio de que les trabajasen las suyas. Hay que tener en cuenta que los colonos buscaban mano de obra barata para fomentar sus inversiones agrícolas.

El malestar generalizado de los Kikuyu por la "tierra robada", se unía a las políticas coloniales que buscaban una proletarización a tiempo parcial de los campesinos, que reforzaban con órdenes tales como la reclusión en reservas, el pago de impuestos, la obligación de tener una tarjeta de identidad y los límites al tipo de cultivos: a los Kikuyu no se les permitía cultivar productos para el mercado, sino solo para su subsistencia.

\subsection{EL GOBIERNO INDIRECTO}

El dominio imperial de la Inglaterra victoriana descansaba en unas reglas administrativas bastante simples que seguían el principio de que las colonias no se convirtiesen en una carga financiera para la metrópolis. En otras palabras, las distintas administraciones de todo el Imperio tenían que buscar una explotación de los recursos y un sistema tributario que permitiese a cada uno de los territorios coloniales autofinanciarse (Elkins, 2005: 7). Cuando se construían grandes infraestructuras -líneas de ferrocarril, carreteras, proyectos de regadío, etc.- se esperaba que fuesen las "beneficiadas" poblaciones nativas quienes con impuestos adicionales -bajo la forma de trabajo en las obras coloniales y de tasas e impuestos especiales- corriesen con los gastos de las obras.

\footnotetext{
5. De hecho, Jomo Kenyatta, discípulo de Malinowski y primer presidente de Kenia siguió esta política una vez lograda la independencia y que es el origen de las graves y peligrosas desigualdades actuales: favoreció que los Kikuyu se establecieran en las granjas que los colonos habían dejado atrás tras la independencia, incluso en aquellas zonas que no pertenecían a su área de influencia, al tiempo que frente a Luos, Masais o Kamba puso en manos Kikuyu la administración, la burocracia y todas las nuevas formas de obtener riqueza y control de los recursos.
} 
De esta forma la célebre "carga del hombre blanco"6, componente fundamental de la misión civilizadora en que se sustentaba la ideología imperial de los victorianos, se repartía de manera desigual entre los redentores civilizados y los atrasados salvajes.

La estructura político-administrativa del dominio colonial, muy descentralizada, se basaba en la coordinación entre tres entidades organizativas: la Colonial Office de Londres; la Administración local compuesta por un cuadro de funcionarios, educados en las instituciones más elitistas de Inglaterra (entre ellas destacarían Eton, Oxford y Cambridge), que actuaban como agentes de la Colonial Office en las colonias concretas y, por último, el Gobierno Central de la colonia, presidido por el Gobernador que se situaban entre la Colonial Office y la Administración local.

En ninguna de las tres instituciones el número de funcionarios era elevado. Así, por ejemplo, en la Administración local de la Kenia colonial trabajaban unos 80 miembros del cuerpo de élite para administrar a unos 5 millones de nativos.

En otras palabras, la colonia no solo tenía que ser autosuficiente económicamente, sino que los órganos de dominio necesitaban recurrir a los propios colonizados. Mediante el llamado gobierno indirecto (indirect rule), los administradores imperiales recrearon o inventaron una organización tradicional de los "nativos", agrupados en unas entidades llamadas "tribus", dirigidas por "jefes", que debían lealtad a la Administración local que les había dado un monopolio para controlar a su gente a cambio de mantener el orden, reclutar trabajadores y recolectar impuestos.

\subsection{EL ORDEN TRIBAL}

La creación de unos "jefes tribales" ha de entenderse como una irrupción de las estructuras coloniales en una sociedad como la Kikuyu que, hasta entonces, había carecido de jefes. Desde el punto de vista político, los Kikuyu habían sido una sociedad acéfala, en las que las decisiones extradomésticas las tomaba un consejo de ancianos en unión de los cabezas de los linajes. Las mujeres también ocupaban un importante lugar en la vida pública a través de sus propios consejos de ancianas, de sus ceremonias exclusivas y de la importancia que tenían como adivinas, profetisas o sanadoras (Shaw, 1995).

Como en muchos otros lugares, el gobierno indirecto al imponer la figura de los jefes

6. La expresión "White man's burden" hace referencia al famoso poema de R. Kipling, en el que quedan patentes los principios básicos de la ideología colonial. Los blancos tenían que civilizar a los pueblos atrasados porque constituían el fragmento superior de una jerarquía que clasificaba las llamadas razas humanas en un orden ascendente en función de sus cualidades intelectuales, morales y políticas. Esa superioridad racial de los blancos les obligaba a "redimir" a los pueblos que por su inferioridad eran incapaces de regirse a sí mismos o de explotar los inmensos recursos puestos a su disposición por la naturaleza o por la providencia. La ideología en que se sustentaba la "carga del hombre blanco" convertía el dominio y la explotación colonial en un deber moral altruista y desinteresado. 
tribales (Elkins, 2005: 19) creó distinciones entre la mayoría de los Kikuyus y una exigua élite de privilegiados entre cuyas tareas estaba reclutar trabajadores -tanto para los proyectos del gobierno colonial como para trabajar las tierras de los colonos- y recaudar impuestos. Es decir, se creó una división social, en cuanto al acceso y control de los recursos, entre gobernantes y gobernados. El conflicto interno entre los Kikuyu proviene de la consolidación de esas diferencias, tras varios años de poder de los jefes -sus familias y consejos tribales-. El historiador Anderson (2005: 11) distingue nítidamente tres grupos sociales que estarían presentes en la conflictividad interna de los años cuarenta. En primer lugar, un grupo de conservadores, partidarios de la colonia, formado por los jefes y sus consejos. Su autoridad, como hemos visto, procedía de la administración colonial, al tiempo que, con sus familias, participaban en la adquisición de tierras, buscaban puestos burocráticos en las ciudades y establecer pequeños negocios. Uno de sus representantes más poderosos, el jefe Warihiu, sería la primera víctima del Mau Mau. Por otra parte, en el grupo que pudiéramos llamar los desposeídos -la gran masa Kikuyu- Anderson distingue dos tendencias: a la primera, compuesta por un sector de nacionalistas moderados, activos en la arena política desde los años 20 , pertenecían un grupo de jóvenes educados en las misiones, con modales, trajes y aspiraciones "europeas", que se oponían a un poderío de los jefes que les dejaba sin posibilidades de encontrar trabajos especializados. Homo Kenyatta y sus compañeros representarían esta tendencia. Pero también había otra más radical, de nacionalismo militante, que incluiría en su agenda todos los problemas relacionados con la escasez de tierras y de salarios, tanto en el campo como en el trabajo informal en Nairobi. Porque la tierra y la proletarización de los campesinos era, como hemos señalado, el gran problema de los Kikuyu.

La política colonial, siguiendo el dualismo entre ciudadano regido por la ley/súbdito o regido por la costumbre que ya hemos visto, aplicaba distintas legislaciones a las tierras de los colonos y a las tierras de las reservas nativas. En el primer caso, la tenencia se basaba en el dominio pleno o en la existencia de alquileres a largo plazo; en el segundo, en la costumbre. La "costumbre" regulaba que las reservas sobreexplotaran las pequeñas parcelas que les habían dejado como una forma de propiedad comunal, administrada por el jefe de la tribu. La desposesión e insuficiencia de tierras obligaba a los hombres a recurrir al trabajo migratorio en las granjas de los blancos, en las minas, en las obras públicas o en la economía informal de las ciudades. A lo largo de los años acabaría por establecerse una política laboral de apartheid que les obligaba a regresar periódicamente a las reservas (reagrupadas en 10 territorios). La "costumbre" establecía que la labor complementaria de un campesino libre fuese el trabajo migratorio; no convertirse en jornaleros o proletarios a tiempo completo. 


\subsection{LA REBELIÓN MAU MAU ${ }^{7}$}

El Mau Mau siempre se ha considerado un movimiento de difícil clasificación porque, por una parte, se nutría de componentes muy locales, con reivindicaciones clásicas sobre la tierra -su lema era ithaka na wiyathi, "tierra y libertad"- expresadas mediante unos rituales de afirmación y lealtad cuyas referencias eran siempre Kikuyu. Se trata de una lucha que podría equipararse con otras guerras campesinas del siglo XX, que además del reparto de tierras acabarían por buscar la autodeterminación política, el fin de los terratenientes o la independencia de las potencias extranjeras (Wolf, 1979).

Para autores como Frank Furedi, Mau Mau era tanto la expresión de los desposeídos Kikuyu como un movimiento de masas, que cuestionaba la estructura socio-económica de la sociedad (Mamdani, 1996: 89). Su base social estaba alejada de las clases medias educadas que aspiraban a convertirse en élites ${ }^{8}$.

Otros análisis, muy extendidos, clasifican el movimiento a partir de la polaridad tribunación. Hay autores para quienes el Mau Mau no dejaría de ser un "pequeño asunto tribal" (Mandani, 1996: 189), porque estaba centrado exclusivamente en los Kikuyu, en sus reivindicaciones y en su revitalización cultural, como muestran sus canciones que reflejan los valores Kikuyu. En el otro polo estarían quienes basándose en su ideología (cánticos Mau Mau de contenido revolucionario), lo consideran un movimiento nacionalista que al asumir la rebelión colonial de Kenia, se fue dotando de aspectos supraétnicos.

Pero, ¿qué era realmente el Mau Mau? Básicamente un movimiento anticolonial, con guerrillas organizadas en la selva, formado por gran parte del pueblo Kikuyu y algunos aliados Meru y Embu, que lucharon en la Kenia Central en los años cincuenta. Muchos de sus líderes provenían de antiguos combatientes, que llevaban desde el final de la guerra mundial acumulando armas y practicando tácticas de guerrillas. Una novedad Mau Mau fue la existencia de mujeres guerreras, algunas de origen urbano, integradas en los grupos guerrilleros que se ocultaban en la selva, construían campamentos, cocinaban y portaban armas. Las mujeres rurales de las reservas fueron básicas en tareas de la retaguardia como la transmisión de información o la distribución de alimentos (Shaw, 1995: 150).

3. EL MAU MAU COMO "NACIONALISMO SELVÁTICO”: EL JURAMENTO DE LOS KIKUYU Y LA MUTILACIÓN GENITAL FEMENINA.

La ambigüedad entre elementos locales y universales nos invita a detenernos en sus

7. Se ignora el significado del término Mau Mau.

8. Tal vez debido a las presiones de los colonos, este fue uno de los grandes errores tácticos de los británicos: asociaron y detuvieron como miembros del Mau Mau a líderes moderados, como Kenyatta y otros que mantenían posturas encontradas con los líderes del movimiento. 
orígenes, para lo que es importante referirse a la primera asociación política, la KCA (Kikuyu Central Association), creada en los años 20 por un grupo de jóvenes Kikuyu, educados por los misioneros9. Las ideas políticas de la Asociación aglutinaban varias vertientes moderadas de nacionalismo y de búsqueda de la independencia política. Conocedores del funcionamiento de las instituciones coloniales, sus promotores canalizaron sus primeras reivindicaciones -sobre la tierra y los salarios agrícolas- tanto a la Administración Local y al Gobierno Central de Nairobi como a la Colonial Office de Londres.

Al igual que sucediera en otras colonias, en un principio podría parecer que las aspiraciones de la KCA reflejaban las demandas de grupos de jóvenes, cuyos recursos provenían de la educación formal que habían adquirido en los centros de los misioneros, y que aspiraban a formar parte de distintos cuadros de las nuevas élites africanas. En el caso de Kenia la administración colonial los dejaba sin espacio para llegar a formar una élite alternativa a la de los jefes tribales y sus redes o a la que ocupaban los propios colonos y las suyas.

\subsection{LOS AÑOS 30: LA CONTROVERSIA SOBRE LA MUTILACIÓN GENITAL FEMENINA}

La KCA cobró fuerza y ganó adeptos entre los Kikuyu cuando la asociación como tal se opuso a la exigencia de los misioneros protestantes de que se prohibiese la llamada “circuncisión” femenina. Los Kikuyu, como los Embu, Meru, Masai o los Kigpisis tenían varias ceremonias de iniciación a la pubertad, tanto para hombres como para mujeres. Una de sus fases incluía la irua, término que denominaba tanto la circuncisión masculina como la llamada "circuncisión femenina", en realidad clitoridectomía ${ }^{10}$.

En las distintas lenguas locales se utilizaba el mismo término para la operación de los hombres y para la de las mujeres (Murray, 1976: 92): en ambos casos sus rituales se asociaban con el paso a la edad adulta. Para las mujeres la clitoridectomía marcaba el paso de niña y mujer y su entrada en los grupos de edad encargados de las tareas hortícolas $y$, por tanto, preparadas para el matrimonio, porque según las reglas culturales sin la "circuncisión" ni hombres ni mujeres podían mantener relaciones sexuales ni casarse.

Varias misiones protestantes quisieron erradicar la irua y las ceremonias iniciáticas femeninas porque consideraron algunos rituales obscenos y otros degradantes. Contrariamente, en el caso de la circuncisión masculina, no solo no pusieron ninguna

\footnotetext{
9. Al frente de la Asociación estaría Homo Kenyatta.

10. Hemos tratado en otro lugar (2010b) las complejas discusiones sobre la ablación en la sociedad Kikuyu, los debates de las antropólogas feministas al respecto y las nuevas posiciones en las que se considera que son las mujeres Kikuyu quienes tienen que protagonizar el debate. Véase también Shaw (1995).
} 
objeción, sino que animaban a los jóvenes a que se operasen en los hospitales de las misiones (Murray, 1976: 92).

$\mathrm{Al}$ oponerse solo a la mutilación femenina, los Kikuyu interpretaron que los británicos querían interferir en los rituales reproductivos. Para agravar las cosas, a mediados de los años 30, siguiendo la campaña de los misioneros, varios miembros de la Administración local pidieron a los Jefes y a sus Consejos Nativos que restringieran esta práctica.

La reacción de los Kikuyu reflejaba claramente su malestar: sin ritos de iniciación femeninos, las mujeres no podrían cultivar las escasas tierras para mantener a una familia, ni casarse, ni tener hijos con lo que los Kikuyu desaparecerían como pueblo. En su defensa de la ablación y en el rechazo a los misioneros protestantes y sus prácticas religiosas llegarían a formar misiones cristianas disidentes, solo Kikuyu que excluían a los misioneros europeos contrarios a la mutilación genital.

Los jóvenes líderes del KCA no solo apoyaron la reacción de los Kikuyu, sino que, mediante los escritos de Homo Kenyatta, defendieron las funciones antropológicas de tales rituales y asociaron las ceremonias a Mumbi, madre mitológica del pueblo y de la tierra Kikuyu.

Kenyatta, que por entonces se encontraba en Londres estudiando antropología con Malinowsi articuló con su ayuda una defensa de la "circuncisión”: "El peso del argumento no radica en la defensa de la operación quirúrgica o sus detalles, sino en comprender que se trata de un rasgo muy importante de la sicología tribal de los Kikuyu, porque esta operación se considera la esencia de una institución que tiene enormes implicaciones sociales, educativas, morales y religiosas que transcienden la operación. Sería imposible para un miembro de la tribu imaginarse la iniciación sin clitoridoctomía (sic). Por tanto, la abolición de la cirugía en esta costumbre significaría la abolición de la institución como un todo"11.

Al presentarse como opositores a la dominación imperial defendiendo una cuestión central para las gentes Kikuyu, el moderado KCA obtendría por primera vez un apoyo popular masivo, al tiempo que sus escritos, al irse extendiendo la alfabetización, serían muy importantes en la formulación o invención de las "tradiciones ancestrales" Kikuyu. Una característica de estos escritos, que como los de Kenyatta, presentaban un pasado idílico y armónico, era que ignoraban los conflictos internos entre los Kikuyu del presente y la complejidad de las relaciones domésticas y de género. Tampoco comprendían que a partir de las desigualdades en el acceso a los recursos se estaba generando una diferenciación de clases, que pronto les llevaría a una situación guerracivilista, en la que los grupos moderados dejarían de estar visibles.

11. La cita de H. Kenyatta procede de Mufaka, Kenneth. "Scottish Missionaries and the Circumcision Controversy in Kenya, 1900-1960", International Review of Scottish Studies, vol 28, 2003. 
Pero, es innegable la importancia que adquirieron los discursos casi nacionalistas, o al menos de afirmación identitaria, que circulaban en periódicos y libros. Por ejemplo, Gakaara, escritor y líder moderado que sería castigado en 1952 en uno de los campos más alejados, y que con la independencia se convertiría en uno de los autores más leídos, había publicado un libro llamado el Credo de Gikuyu y Mumbi del que vamos a transcribir un párrafo porque en cuatro líneas encaja armoniosamente el Dios de la Biblia, la mitología, los robos del colonialismo, las ceremonias Kikuyu y la legitimidad de la lucha:

"Creo en Dios, Padre Poderoso, creador del cielo y de la tierra. Y creo en Gikuyu y Mumbi, nuestros queridos padres ancestrales a quienes Dios legó esta nuestra tierra. Sus hijos fueron perseguidos en la época de Cege y Waiyaki por el clan de la gente blanca, que les robaron su gobierno y su tierra y los relegaron al status de siervos humillados. Los hijos de sus hijos que tenían los ojos abiertos, se iluminaron con un gran consciencia y lucharon para reinstaurar a sus padres en sus tronos de gloria.

Y yo creo en las sagradas ceremonias religiosas de Gikuyu y Mumbi, y creo en el buen liderazgo de Kenyatta y Mbiyu y la indestructible solidaridad entre las generaciones Mwangi e Irungu y la unidad de los nueve clanes Gikuyu y en la siempreviva Nación de Gikuyu"12.

La controversia sobre la ablación hizo que las autoridades coloniales considerasen que el KCA era un movimiento "salvajemente" radical y sus líderes sospechosos... en general. Por ejemplo, nada más iniciarse la II Guerra Mundial, el gobierno de la colonia ilegalizó el KCA con el pretexto de que su proyecto político más inmediato era unirse a los fascistas italianos de Abisinia para luchar contra los británicos. Más tarde, todos sus dirigentes serían detenidos, acusados de liderar el Mau Mau, a pesar de que muchos de ellos, notablemente Kenyatta eran moderados y se oponían al movimiento.

Pero, la guerra mundial tendría otras dos consecuencias directas para la radicalización de la protesta que terminaría en la creación del Mau Mau. En primer lugar, porque la "economía de guerra" de la metrópolis hizo muy rentables las explotaciones agrícolas de los colonos, al tiempo que agudizó las diferencias agrícolas entre los Kikuyu desposeídos y los que acaparaban las tierras. Los colonos blancos -y algunos jefes Kikuyu- vivieron en estos años un auténtico boom económico e incrementaron su cuota de poder local al ser los únicos que podían suministrar los productos demandados. Frente a ellos y dada la falta de productividad que arrastraban las tierras de las reservas, las autoridades

12. La cita proviene de Elkin, 2005:202. 
obligaron a los Kikuyu a cultivar para su subsistencia, prohibiéndoles la producción de cosechas para el mercado.

El final de la guerra todavía empeoró más las cosas: las autoridades coloniales, igual que al final de la I Guerra, hicieron un nuevo reparto de tierras para atraer a los militares blancos que al licenciarse buscaban una nueva vida en las colonias. Muchos de ellos decidieron establecerse en Kenia siguiendo los planes del gobierno británico y las facilidades para establecer granjas. Por el contrario, los veteranos Kikuyu, que también habían combatido en la II Guerra Mundial, no recibieron ninguna donación de tierras y las únicas opciones posibles a su alcance eran regresar a la reserva, trabajar para los blancos o dedicarse a la economía informal en las ciudades. Muchos Kikuyu habían combatido en Birmania y en la India, y convivido con soldados que formaban parte de partidos y grupos que mostraban abiertamente su resistencia al dominio colonial y se preparaban para luchar por la independencia.

\subsection{LOS JURAMENTOS KIKUYU: 1948-1952}

Las primeras manifestaciones de resistencia comenzarían cuando se obligó a unos 20.000 Kikuyu que cultivaban en sistema de aparcería tierras ocupadas próximas a las de los colonos, a abandonar los "territorios blancos". Tras ser realojados en una zona llamada Olenguruvone fueron amenazados con una nueva orden de expulsión: unos 143 de ellos recurrieron a un ritual, característico de las ceremonias de solidaridad masculina, en el que se expresaba mediante un juramento su adhesión a los camaradas. El juramente se propagó a través de todas las instituciones Kikuyu, incluidas las iglesias independientes que, como hemos dicho antes, se habían establecido en la época de las protestas por la ablación.

Los juramentos se extendieron entre los Kikuyu, excepto entre quienes formaban parte de las jefaturas tribales y se mantenían leales a los británicos: tanto lo prestaban artesanos, comerciantes, empleados, burócratas, parados, delincuentes, prostitutas de Nairobi, agricultores de las reservas, asalariados de las granjas o aparceros ocupas, como ancianos, mujeres y niños. Según cálculos de los británicos, entre 1948 y 1952 el 90\% de los Kikuyu, más de millón y medio de personas, habían pronunciado el juramento (Elkin, 2005: 27).

En realidad más que de un único juramento, muchos autores hablan de siete grados de juramento, siguiendo un orden ascendente de compromiso. Más tarde, la propia marcha del conflicto transformaría los grados de lealtad expresados. Por ejemplo, el batuni, también conocido como juramento del guerrero, de muerte o superior, se propagó cuando los británicos declararon el estado de excepción: en él, quienes se adherían al Mau Mau, prometían matar o destruir a los colonos blancos (Shaw, 1995). 
Al utilizarse como elemento simbólico de las reivindicaciones, el juramento dejó de ser una práctica en la que se exhibía la solidaridad masculina, para convertirse en un acto de afirmación política frente a las injusticias padecidas que se aproximaba a las protestas de la economía moral tan bien analizadas por E.P. Thompson.

Formalmente los juramentos tenían muchos componentes novedosos que reflejaban cómo el propio colonialismo estaba detrás de la reformulación política de las variaciones culturales: la implicación e importancia de las mujeres en todo el movimiento cobra sentido si consideramos que las relaciones de género estaban cambiando; la Biblia además de un puñado de tierra- estaba presente en las ceremonias, mostrando la unión de símbolos procedentes de distintas series sagradas, como hemos visto en la cita de Gakaara. Por último, no podemos olvidar que las ceremonias suponían un pacto moral, porque es imprescindible comprender que los Kikuyu creían en el poder del juramento. Un juramento, que, por otra parte, medía la popularidad del nuevo movimiento de resistencia llamado Mau Mau.

La desarticulación del moderado KAU supuso un cambio de liderazgo y de objetivos políticos. Se había dejado paso a los soldados que eran partidarios de la lucha armada contra los jefes tribales y contra los colonos. Desde la aparición pública del Mau Mau, las autoridades coloniales fomentaron la división existente entre la masa de Kikuyu excluidos y aquellas cortes de privilegiados que habían surgido en torno a la creación de los jefes. A su vez, muchos jefes tribales, para quienes la existencia del Mau Mau o de independentistas ponía en peligro sus intereses, crearon sus propias fuerzas policiales para oponerse al Mau Mau, de modo que, como señala Anderson "mientras que el Mau Mau dividió a los Kikuyu, unió a los colonos blancos como nunca lo habían estado antes" (Anderson, 2005: 86).

Mientras que la propaganda siempre ha presentado la guerra como si fuese la de los negros contra los blancos, la realidad fue que, según estiman los historiadores (Anderson, 2005), solo murieron 32 colonos blancos y no hubo más de doscientos heridos de los regimientos del ejército y de la policía estacionados en Kenia. La mayoría de las víctimas fueron africanas: el Mau Mau asesinó a unos 1.800 Kikuyu leales a los británicos, a los que habría que añadir varios cientos cuyos cadáveres nunca aparecieron. De hecho, la primera víctima del Mau Mau sería Waruhiu, un importante jefe tribal, cuyo asesinato en 1952 fue la causa alegada para proclamar el Estado de Excepción que se extendería hasta 1960.

Anderson estima que más de 20.000 miembros del Mau Mau murieron en combate, en un momento en que la población Kikuyu era de aproximadamente un millón y medio de personas. De ellos, más de 150.000 estuvieron encerrados en campos de concentración, aunque todo el país se convirtió en uno gigantesco, porque no había mucha diferencia entre los campos y las aldeas rodeadas de alambradas en las que se obligaba a residir a la población (Anderson, 2005: 5-9). Entre abril del 53 y diciembre del 56, hubo en los 
tribunales de Kenia 1200 juicios contra el Mau Mau. En ellos se condenó a la horca, con ejecución de sentencia, a 1574 personas. $^{13}$

\subsection{LA FRONTERA ENTRE SALVAJISMO Y CIVILIZACIÓN}

La guerra contra el Mau Mau se presentó como la lucha de la civilización europea frente al salvajismo africano. Ideológicamente pasaría a ser parte de la carga del hombre blanco: oponerse a la tesis de los misioneros sobre la ablación ilustraba las reacciones del salvajismo africano frente a la misión civilizadora de los blancos. Que lo hiciesen jóvenes, como los del KCA, con formación y estudios europeos se interpretaba bajo este mismo prisma: una muestra de que la civilización europea transmitida a los jóvenes más educados era solo -como se decía- un barniz superficial que, si se raspaba, desvelaba el atavismo africano.

Los juramentos también se incluirían en los relatos que circulaban entre colonos como otra ilustración del salvajismo. Sus ceremonias se representaban como el dominio de la barbarie: la sexualidad imaginada de las mujeres que juraban, la violencia de las palabras o el miedo ante un rito maligno. Todos estos elementos reforzaban el estereotipo del "negro salvaje", un primitivo incapaz de entender las bondades de la civilización.

Uno de los países donde el discurso que presentaba al Mau Mau como si fuese una frontera imaginada entre la civilización blanca y el salvajismo africano tuvo más repercusión fue en los Estados Unidos, porque, según la antropóloga Carolyn Shaw (1995), se trataba de una imagen aplicable directamente a los afroamericanos que empezaban a cuestionar su situación y a buscar que se les reconocieran sus derechos civiles. La frontera entre salvajescivilizados pasó a ser en los medios de los americanos blancos de los años cincuenta una ilustración de los peligros que amenazaban a las democracias occidentales cuando la agitación comunista conquistaba a las razas inferiores: esa temible tríada formada por comunismo, raza negra y sexualidad desbocada.

La polarización civilización-salvajismo impidió que el público de las metrópolis se diese cuenta de que estaban ante una guerra terrible que se cebaba en "concentrar" civiles entre alambradas, en la que la tortura, las violaciones y vejaciones sexuales a hombres y mujeres y el número de muertos tuvieron un alcance cercano al genocidio.

\section{CONFLICTOS ÉTNICOS, GENOCIDIOS Y CUERPOS DE MUJERES}

No hace mucho, la antropóloga Veena Das (2008) se preguntaba en un artículo qué ocurre

\footnotetext{
13. Comparadas estas cifras con las de los juicios en Argelia por terrorismo, las de Kenia duplican las de la colonia francesa (Anderson, 2005: 7). Tampoco se podrían comparar con las de otras colonias británicas, como Palestina, Malaya o Chipre. Todo esto mientras en el Parlamento de Londres se discutía la abolición de la pena capital. La documentación de los tribunales de justicia ha sido magníficamente estudiada por Anderson.
} 
cuando el "contrato social" se "sexualiza". La autora argumenta que, cuando utilizamos modelos de "contrato", aceptamos que el social establece un nivel razonable de consenso en el orden político, mientras que unos acuerdos explícitos que Das denomina "contrato sexual", lo establece en el doméstico.

Creo que la pregunta inicial que se hacía Das es doblemente relevante en nuestro caso. En primer lugar, para entender cómo y porqué el conflicto Mau Mau, que cuestionaba el contrato social vigente en la Kenia colonial, se acompañó de una reestructuración de las relaciones de género, debido, entre otros motivos, a la participación activa de las mujeres en los juramentos, en el aprovisionamiento desde las aldeas a los rebeldes e incluso en su incorporación a la guerrilla en la selva.

Pero también es interesante aplicar las reflexiones de Das al sufrimiento padecido en los campos y en las aldeas alambradas. Como ocurre en muchos otros regímenes de terror, gran parte de la represión en los distintos campos de internamiento puede inscribirse en un proceso conducente a deshumanizar a las víctimas, de forma que los verdugos dejen de considerar que comparten con ellas la humanidad. (Moreno Feliu, 2010: 78-79).

En el caso de Kenia el modelo colonial que hacía ver a los acusados del Mau Mau como salvajes irredentos, les facilitó enormemente la tarea. Sin embargo hay un aspecto muy llamativo por su recurrencia: el ejercicio de la violencia sexual que se manifestaba en diversas violaciones del cuerpo de los prisioneros, tanto hombres como mujeres. Siguiendo la tesis de Das podemos buscar explicaciones en cómo el "contrato social" y el "contrato sexual", que en las épocas de paz señalan su presencia en el ámbito político y en el doméstico respectivamente, pierden su vigencia en unos conflictos en los que cualquier noción de consenso se convierte en irrelevante, mientras que quienes ejercen un poder absoluto sobre sus víctimas terminan por sexualizar su dominio.

Antropólogos como Joan Frigolé (2003) ya habían señalado que una de las características de los genocidios -el ataque o impedir la reproducción-adapta múltiples formas: "matanza indiscriminada de hombres y mujeres, de niños e incluso de no nacidos; agresiones a los órganos de reproducción masculinos y femeninos; violaciones de mujeres; escarnio de la procreación; separación forzada y robo de niños; mortalidad elevada a causa de la precariedad impuesta por el agresor, etc. (Frigolé, 2003).

Sabemos que en las diversas reclamaciones judiciales que actualmente han entablado varios grupos de supervivientes Kikuyu, la palabra genocidio se empieza a escuchar, en diversas salas de justicia, ligada a delitos de violencia sexual extrema, como la castración o la violación. Pero no vamos a entrar ahora en una discusión nominalista o jurídica sobre el genocidio, sino a adentrarnos en el análisis de cómo la violencia sexual llegó a dominar todo el proceso represivo de los diez años del estado de excepción, de forma que pareciera que si en la paz "el contrato sexual” se restringe al ámbito doméstico, en la guerra Mau Mau el poder absoluto “sexualizó” la violencia. 


\subsection{EL MAU MAU Y LA REESTRUCTURACIÓN DE LAS RELACIONES DE GÉNERO.}

Uno de los aspectos menos estudiados del Mau Mau fue el decisivo papel jugado por las mujeres Kikuyu. Louise White, autora de una excelente investigación sobre la prostitución en la ciudad de Nairobi, mantiene que durante los años de guerra y represión se produjo una reestructuración de las relaciones de género.

En su trabajo había seguido -en los años anteriores al estado de excepción- la encarnizada campaña de los líderes más radicales del Mau Mau a favor de una supuesta moralidad doméstica que reelaboraba las relaciones de género ideales que supuestamente caracterizaban a la tradición Kikuyu. Se oponían a la prostitución, a que las jóvenes que no aceptaban los matrimonios que les había asignado su familia se escapasen a Nairobi, o a los matrimonios monógamos frente a la poliginia. Según White, los lideres Mau Mau habían dedicado más páginas a escribir sobre el matrimonio que sobre ningún otro tema. Por eso, encuentra sorprendente que "en muchos casos, los mismos hombres que en 1950 habían pretendido criminalizar la conducta de los hombres que iban con prostitutas o la de las hijas fugitivas, tres años más tarde, en la selva permitiesen que las mujeres fuesen armadas e insistieran en los matrimonios monógamos".

Aunque son escasos los datos que tenemos sobre la vida de las mujeres en la selva, los cambios en las relaciones de género fueron tan impresionantes que L. White propone sustituir la cronología habitual de la guerrilla Mau Mau (1952, los lideres se escapan a la selva; 1953, división del liderazgo entre Dedan Kimathi y Stanley Mathengue; 1954, se constituye en la selva el Parlamento de Kenia; febrero-marzo 1955, negociaciones de rendición; octubre 1956, captura de Kimathi; diciembre 1956, se marcha el ejército británico), por otra referida a los cambios en las relaciones de género y que sería algo así: "diciembre 1952, los lideres en la selva; julio 1953, conferencia a favor del matrimonio monógamo; agosto 1953, las mujeres obtienen status de guerreras; marzo 1954, el grupo de Mathengue prohíbe que se mantengan relaciones sexuales en la selva; marzo 1955, Dedan Kimanthi nombrado primer ministro en una ceremonia del Parlamento Keniata y su amante Wanjiru, nombrada su reina, Caballeros comandantes de Gikuyu y Mumbi” (White, 1990b:11).

Fuera de la guerrilla, tanto en Nairobi como en las aldeas, el estado de excepción también cambió la vida de las mujeres, muchas de ellas perseguidas como miembros del Mau Mau. En primer lugar, porque muchas se quedaron sin los hombres de su familia, ya fuese porque estuviesen en la selva, ya porque estuviesen detenidos. En esos casos las autoridades y sus colaboradores buscaban a las mujeres para que los delatasen o diesen nombre de sus contactos.

Pero, también porque, como miles de mujeres Kikuyu habían proferido el juramento, se las consideraba sospechosas de ser miembros del Mau Mau, ya fuese activamente, ya como la retaguardia del movimiento con el encargo de suministrar a la guerrilla 
información, alimentos, armas o medicinas (Elkins, 2005: 219-225).

La campaña de propaganda, tan importante como la militar, incorporaba "fantasías sobre la sexualidad africana" se imaginaban que la sangre menstrual -llamada monthlies en el dogma oficial- se incorporaba a los juramentos, haciéndolos más graves y siniestros. La selva con mujeres guerreras, portadoras de armas, mostraba el salvajismo de la lucha: "El Mau Mau, con sus juramentos, sus asesinatos y la vida en la selva era, en palabras de un británico, como si se hubiese borrado medio siglo de administración y civilización" (White, 1990b:15). Mientras, gran parte de la campaña británica sobre las mujeres giraba en torno a las prostitutas ${ }^{14}$, presentadas como una quinta columna Mau Mau especializada en obtener información de los soldados Kikuyu leales o en asfixiarles para robarles las armas.

\subsection{LA SEXUALIZACIÓN DE LA VIOLENCIA}

A pesar de que había una campaña de silencio sobre el sistema concentracionario de Kenia, los detenidos de los campos, muchos de ellos intelectuales, lograron escribir muchas cartas que, a veces, mediante sobornos a los guardianes, lograban salir al exterior ${ }^{15}$. En todas estas cartas hay un tema recurrente: el de la violencia sexual.

La forma en que se desarrolló en Kenia lo que en otra parte hemos llamado proceso de deshumanización de las víctimas (Moreno Feliu, 2010) seguía un discurso racista. Recordemos que según esas doctrinas existen grupos humanos, llamados razas, cuyos miembros comparten ciertas características físicas y ciertos rasgos culturales e individuales que determinan sus capacidades intelectuales y sus conductas morales. Según los numerosos seguidores de esas doctrinas, las razas se presentan ordenadas jerárquicamente, de modo que las situadas en la escala superior pueden dominar a las otras. En la ideología dominante entre los colonos blancos, los británicos, caucásicos, pertenecientes a la raza superior, tendrían unas aptitudes intelectuales y morales superiores a razas inferiores, como las de los Kikuyu -negroides- que vivían según sus instintos más primarios, el más notable el sexual: "según el mito europeo, los hombres negros tenían penes de un tamaño digno de Gargantúa y si se les diese la oportunidad, esos 'salvajes' tan bien dotados violarían a las mujeres blancas.' (Elkins, 2005: 208).

\footnotetext{
14. Algunas autoras feministas han señalado que esa campaña también buscaba minimizar el papel de las mujeres "decentes" en la lucha Mau Mau, al destacar a las prostitutas como guerreras: incluso se decía que había una organización de prostitutas Kikuyu que habían jurado.

15. Estas cartas iban dirigidas a diversos tribunales, autoridades de la colonia, miembros del partido laboralista en Londres. En ellas se describen las atrocidades cotidianas, en medio de preguntas sobre la intención de los campos que se comparan con los nazis. Estas cartas, muchas en archivos oficiales, en compañía de testimonios orales recogidos por diversos investigadores es una valiosa fuente de datos para saber lo ocurrido tras las alambradas.
} 
Independientemente de la ideología subyacente, la deshumanización de las víctimas pasaba por ejercer torturas no contra el cuerpo, sino contra la sexualidad salvaje que le achacaban a esos cuerpos, como si la manera de dominarlos no fuese "social", sino "sexual".

Sabemos de la protesta constante en las cartas contra la humillación sexual a la que se les sometía, sobre todo a la sodomía (no solo sexo forzado, sino también la introducción en el recto de todo tipo de objetos, animales, insectos vivos o plantas) que era habitual en los interrogatorios. Elkins vincula estas torturas con el discurso ideológico dominante entre los colonos blancos: "El peligro negro, la supuesta capacidad sexual de los varones africanos representaba una amenaza a la sexualidad de los europeos y por extensión a la capacidad europea de establecer y mantener su dominio en las colonias africanas." (Elkins, 2005: 208).

La violencia sexual ejercida contra los varones Kikuyu, así como los abundantes casos de castración registrados, nos remite a la idea inicial de que los ataques contra el cuerpo representaban una sexualización de la violencia, en la que el poder político colonial pretendía dominar todos los principios de la masculinidad Kikuyu: la tierra, las mujeres, sus descendientes, e incluso su propio cuerpo.

\subsection{EL CUERPO DE LAS MUJERES.}

Una de las medidas adoptadas durante el estado de excepción fue obligar a todos los Kikuyu rurales a asentarse en aldeas, con la doble pretensión de romper la ayuda a las guerrillas Mau Mau que combatían en la selva y de aumentar el control de los jefes tribales, en cuyas manos quedarían muchos procesos de "rehabilitación" de condenados. De este modo, las aldeas, rodeadas de alambradas y vigiladas por soldados armados, se asimilaron a campos de detención (Elkins, 2005: 237), sobre todo para mujeres, ancianos y niños. Recordemos que en Kenia las aldeas se regían por un jefe leal a los británicos, que contaba con una policía militar para imponer las medidas del estado de excepción. Las fuerzas Kikuyu fueron fundamentales para que la represión se ejerciera en todas partes: conocían a la gente, sospechaban o sabían quiénes podían haber jurado y quiénes tenían familiares en la guerrilla o prisioneros en los campos.

Los colonos contaron con la ayuda de Kikuyus leales a los británicos, que, asimilando la situación a la de una guerra civil (Elkins,2005: 69), actuaban a veces a cara descubierta, mientras que otras, ocultaban su identidad con un pasamontañas que les permitía participar en los interrogatorios y torturas, enviar a la gente a campos de detención y confiscar tierras y propiedades de los detenidos.

Las mujeres también estaban sometidas a un régimen de terror. Residían en sus cabañas y cultivaban las tierras escasas de las reservas para alimentar a su familia, pero tenían que realizar trabajos forzados. Cuando había ataques del Mau Mau toda la aldea permanecía 
alerta, mientras "interrogaban" a las mujeres en las cabañas o las sometían a castigos colectivos.

También, como en el caso de los hombres, la violencia de soldados, colonos y jefes Kikuyu con sus milicias domésticas se había sexualizado, sobre todo en los interrogatorios a los que se veían sometidas para averiguar si ayudaban a las guerrillas en la selva: "A veces los Guardias Domésticos tomaban la iniciativa y retorcían y mutilaban los pechos femeninos con alicates; introducían gusanos y rifles en su vagina y las forzaban a correr desnudas por el puesto de guardia llevando un cubo de excrementos en la cabeza" (Elkins, 2005: 244).

Durante los diez años del estado de excepción las penalidades sufridas por las mujeres en las aldeas en poco se diferenciaban del trato dispensado a las reclusas de los campos: leyendo la literatura testimonial da la impresión de que la diferencia aldea-campo era una cuestión de grado.

Las violaciones eran corrientes: "A veces hombres, tanto blancos como negros, de las fuerzas de seguridad violaban juntas, en la misma cabaña, a madres e hijas" (Elkins, 2005: 247). Al igual que en las aldeas o en los campos masculinos, también eran sometidas a violaciones y vejaciones sexuales: les introducían en sus cuerpos botellas, huevos calientes y otros objetos, sobre todo durante la fase de interrogatorios, el llamado "screening", con el fin de que confesasen y delatasen a miembros del Mau Mau entre su círculo de familiares y conocidos.

Las torturas específicas para las mujeres, sobre todo en las sesiones de "screening", se repiten en los relatos orales recogidos por Elkins. Margaret, por entonces una joven a la que un hombre blanco a quien los Kikuyu apodaban Karoki -el que llega al amanecerinterrogó en una cabaña de la finca del colono para el que trabajaba, le cuenta a Elkin cómo fue torturada: "Me preguntó el número de juramentos que había realizado, donde estaba mi esposo, a dónde habían ido mis hermanastros [estaban en la selva]. Desnuda, me azotaron horriblemente, sin importarles que acababa de parir, mi bebé tuvo suerte de que no le mataran como al resto. ...Aparte de golpearnos, a las mujeres nos metían hojas y flores de banano por la vagina y el recto y nos retorcían los pechos con unos alicates; después de eso una mujer confesaría cualquier cosa para evitar el dolor... a los hombres les retorcían los testículos con los alicates para que confesaran. Después de que me hicieran tales cosas, les dije todo. Sobreviví la tortura, pero todavía hoy siento el dolor en mi cuerpo." (Elkins, 2005: 68).

También había mujeres con sus hijos internadas en campos como el de Kamiti. La transformación que sufrieron en sus encierros como consecuencia de las torturas físicas y mentales, enfermedades, trabajo exhaustivo, prohibiciones de todo tipo, incluida la de cantar en Kikuyo, la ausencia de higiene, la escasez de alimentos y la angustia y preocupación por sus hijos daría a las reclusas la apariencia de "salvajes", tan querida por la ideología de sus perseguidores. 
$\mathrm{Al}$ igual que en el caso de los hombres, se han logrado rescatar algunas cartas que las mujeres de Kamiti habían enviado a varios tribunales de justicia o a la parlamentaria laborista Barbara Castle, denunciando su situación. Como en esta carta sin fecha y sin firma encontrada por Elkin en un archivo: "Los bebés y los niños [están] subalimentados. No les dan suficiente leche y la dieta está desequilibrada. Lloran todo el día. Obligan a las mujeres a que cocinen para sí mismas, pero no les dan la comida suficiente. Hay mujeres que mueren por el tratamiento brutal que han sufrido en prisión. Hay muchas enfermedades entre las prisioneras, tuberculosis y tifus son las más corrientes. Muchas mujeres han muerto de estas enfermedades. Los funcionarios torturan a nuestras mujeres y las obligan a confesar cosas que ignoran. Empezamos a trabajar a las 6 de la mañana y terminamos a las 7 de la tarde. Nos golpean constantemente mientras trabajamos. Nos envían a las granjas de los europeos, situadas a muchas millas del campo, andando y corriendo, y golpean a quienes andan despacio, por su mala salud. Se desatiende a los niños si están enfermos y mueren como animales." (Elkins, 2005: 228).

La violencia ejercida contra las mujeres y sus hijos parece seguir la misma lógica de destrucción colectiva que hemos visto en el caso de los hombres. Cuando hacia 1960 concluyó formalmente el estado de excepción, los hombres que habían estado recluidos en los campos y regresaron a sus casas, se encontraron un panorama desolador: aldeas $\mathrm{y}$ asentamientos desconocidos, muchas esposas, padres, madres o hijos muertos y enterrados fuera de las aldeas. Muchas mujeres habían tenido hijos de sus violadores, algunos, los llamados nusu-nusu, recordaban a los colonos blancos; otros, a los vecinos Kikuyu que habían trabajado para los ingleses.

Das (2008: 291) sostiene que, en muchos casos de genocidio, las violaciones de las mujeres tienen un mensaje para los hombres de su familia: la de producir hijos bastardos como una ofensa contra quienes tienen los derechos legales sobre la descendencia y como una forma de destruir los vínculos domésticos que regían el contrato sexual en tiempos de paz: "Las violaciones en grupo de las mujeres, la violencia reproductiva que asume las formas de embarazos forzosos o la obligación de matrimonios forzados que están presentes en los proyectos de limpieza étnica y de genocidio son diferentes formas de aniquilar completamente al otro como comunidad colectiva."

\section{LA CIVILIZACIÓN DE LAS ALAMBRADAS}

La reacción británica ante el Mau Mau fue doble: combatirlo militarmente y combatir civilmente las maldades del juramento. Este último episodio, encuadrado en el estado 
de excepción, acabaría por desencadenar la creación de más de cien campos $^{16}$ de internamiento, reeducación o concentración, cuya misión -se decía- no era penal, sino civilizar a quienes habían regresado a los estadios de la barbarie. La idea de que los "salvajes" Mau Mau no compartían humanidad con sus enemigos estaba presente en los soldados blancos y Kikuyu leales que desfilaban durante aquellos años, como recuerda un hombre de Kiambu: "Desfilaban por la calle principal, en filas y con sus mochilas a la espalda. El hombre blanco que comandaba gritaba “¿quiénes son los malditos salvajes?”. Los otros soldados blancos y sus askaris negros respondían: "Mau Mau". Entonces decía: “¿Cuáles son las órdenes?” Y le contestaban, "matarlos".

Puede que la creación de los campos y alambrar las aldeas representase para sus creadores "la verdadera naturaleza de la misión civilizadora" del imperio. Pero, la vida tras las alambradas se asemeja como dos gotas de agua a la sufrida por los prisioneros en los Gulag y Lager.

$\mathrm{Al}$ instaurarse los campos, las autoridades comprobaron que el sector de los detenidos alfabetizados enseñaban a leer a los analfabetos reforzando sus reivindicaciones. Por ejemplo, pronto descubrieron que las Biblias que les dejaban los misioneros para que regresasen a la "civilización", se reinterpretaban en claves netamente políticas, en las que los padecimientos de los Kikuyu en los campos se asimilaban a los de los Hijos de Israel. Como había explicado el Comandante de Auschwitz en sus Memorias, la administración de unos campos en los que están recluidos miles de prisioneros se sustenta en saber aplicar los viejos principios del "divide y vencerás". (Moreno Feliu, 2010). También en Kenia se aplicarían estas políticas. Por una parte, los dirigentes Kikuyu serían enviados a los campos más alejados e incomunicados. Por otra, en cada campo se pusieron en marcha políticas que dispersasen a los prisioneros, separándolos según diversos sistemas de clasificación que daban cuenta de su grado de peligrosidad, de su cooperación con las autoridades o de su capacidad de reinserción en las aldeas, también rodeadas de alambradas y dirigidas, como hemos visto, por los jefes Kikuyu que eran leales a los británicos.

En algunos campos se ideó un sistema basado en dividir a prisioneros en tres colores básicos: el negro se aplicaba a la cúpula dirigente (los "hard core"); el gris, a militantes que habían pronunciado varios juramentos; mientras que el blanco denotaba que el prisionero era "recuperable"17.

16. Hay controversias sobre el número de campos que llegó a haber en Kenia. La mayoría de historiadores sostienen que su número superaba el centenar. Como en otros episodios similares ha habido una inmensa destrucción de pruebas que ha impedido consultar la documentación. Las mismas controversias existen sobre número de víctimas, de miembros del Mau Mau o de detenidos.

17. En otros campos los términos eran A "hard core" para los dirigentes, B "old and stupid" y C "reclamaible". 
Una de las encargadas del campo de Kamiti ${ }^{18}$, donde había más de tres mil mujeres reclusas, ideó una clasificación que incorporaba brazaletes o argollas metálicas para que se reconociese la posición en la "jerarquía del mal" de las prisioneras: así quienes portaban un único brazalete eran las más involucradas o "negras"; dos pulseras identificaban a las "grises" y tres a las "blancas". Siguiendo esta misma pauta, las prisioneras de Kamiti residían en distintas partes del campo simbolizadas con nombres de animales: las más peligrosas, es decir, las "negras" residían en la parte denominada "hienas"; las "grises oscuras", en la parte llamada "cabra". El resto de los lugares del campo, donde residían las menos "salvajes", recibía los distintos nombres que se aplicaban al ganado vacuno según su edad: las grises, al denominado "ternera"; las "grises claras", al llamado "ternera lechal" y las "blancas", al que tenía el nombre de la vaca madura. Esta asimilación de los prisioneros a la jerarquía de animales, siguiendo las clasificaciones culturales Kikuyu, tenía sus efectos: "Nuestra cooperación se hacía equivaler con distintos animales que tenían significados importantes para nosotras como Kikuyu. Esto nos irritaba profundamente, porque sabíamos que Mahuru intentaba ser inteligente. Pretendía actuar como si fuese una de nosotras, pero ninguna verdadera Kikuyu se comportaría como ella lo hacía." (Elkins, 2005, 223).

La simbología de los colores seguía una jerarquía netamente racista, en la que un negro, equivalente a salvaje africano (Mau Mau) para llegar a la civilización tendría que atravesar distintos estadios (los grises) hasta convertirse en blanco: para ser netamente civilizado un Kikuyu tendría que ser blanco.

Las redadas de Kikuyu sospechosos, su internamiento, su clasificación en "blancos, grises o negros" según su proximidad a la civilización de los colonos, los temibles screening o interrogatorios bajo tortura, la jerarquía de campos según sus misiones (centros de recepción, reclusión, trabajo, castigo, para mujeres, para niños o para sospechosos de otros grupos ya fuesen Kamba o Masai), así como la rutina burocrática, cada vez más eficiente y centralizada, siguió pautas que encontramos en otras situaciones similares, como señala Elkins (2005: 153): "un microcosmos en el que hervían las contradicciones y antagonismos entre las sociedades Kikuyu y europeas en Kenia y donde el mundo tras las alambradas mostró con toda transparencia la cara oscura del proyecto colonial británico."

De hecho, ahora que con el juicio han salido a la luz algunos de los documentos celosamente guardados durante todos estos años, entendemos mejor la carta que en 1957 Eric Griffith-Jones, el fiscal general de la administración británica en Kenia, escribió

18. Katherine Warren-Gash, que se hacía llamar Mahuru, era la hija de un colono blanco que presumía de conocer las costumbres Kikuyu. Era la encargada de los interrogatorios y de diversos aspectos administrativos del campo. Sus tácticas incluían diversos tipos de torturas como palizas, reducción de raciones y amenazas a los niños que estaban detenidos con sus madres. 
a Sir Evelyn Baring, gobernador de la colonia, rogándole el máximo silencio sobre el régimen de terror que habían impuesto en el país: "Si vamos a pecar, debemos hacerlo silenciosamente"19. Los cientos de documentos que dan cuenta del "pecado" en Kenia -y en otros lugares del imperio- no se habían enviado a los archivos históricos de Kew: permanecían ocultos en una cámara secreta en Hanslope Park, bajo instrucciones de que no deberían transferirse a ningún gobierno tras la independencia porque podrían causar problemas a los funcionarios. En ellos se detalla también la destrucción de miles de documentos que las distintas ramas de la administración habían reducido a cenizas o arrojado al mar.

Sin embargo son numerosísimos los documento ${ }^{20}$ que desvelan, en el caso de Kenia, las políticas generales y cómo algunos sospechosos habían muerto a golpes; otros, quemados vivos, torturados, castrados o esposados durante años. No es de extrañar que el mismo fiscal general que recomendaba pecar en silencio, en un comunicado interno reconociese que el trato dispensado a los prisioneros "era dolorosamente reminiscente de las condiciones en la Alemania Nazi o en la Rusia comunista".

\section{AQUELLA AMNESIA IMPERIAL Y POSTCOLONIAL}

Entre 1952 y 1960 los británicos desmantelaron la guerrilla Mau Mau, establecieron un estado de excepción aterrador y encerraron a un porcentaje considerable de la población. Paradójicamente, la derrota militar supuso para los Kikuyu una doble victoria política: rompió el poderío político de los colonos, para quienes Kenia, como señala Anderson en el prólogo a su libro (2005), había sido hasta entonces el paraíso descrito en la literatura de Karen Blixen. También dio al traste con el proyecto político de los colonos de que Kenia -como la Rhodesia postcolonial o Sudáfrica- se transformase en el "país del hombre blanco" en África. La segunda fue, como destaca el historiador africanista H. Wilson (1977: 304-311) que la rebelión Mau Mau desencadenó los procesos descolonizadores de las colonias británicas del este de África, incluido el de Kenia, a cuyo frente han estado siempre los Kikuyu .

Sin embargo, los miembros del Mau Mau no se beneficiaron de la independencia. Otros lideres moderados y los propios Kikuyu colaboradores tomaron las riendas del país tras la independencia.

Kenyatta, liberado en 1961, sería el primer presidente electo del país cuando en 1963 se proclamó la independencia. A partir de ese momento, integrando en su gobierno junto a los miembros de su partido a los antiguos jefes y a otro número de colaboracionistas,

19. Ian Cobain y Richard Norton-Taylor, 18 Abril 2012, Sins of colonialists lay concealed for decades in secret archive. The Guardian. El artículo desvela el contenido de algunos de los documentos secretos de la Foreign and Commonwalth Office (FCO).

20. Gran parte de los archivos todavía no se pueden consultar. 
las políticas que llevó a cabo se inclinaron por una política llamada de "reconciliación nacional", basada en el olvido de la represión anti Mau Mau: las proclamas ideológicas de la nueva nación decían rendir tributo a todos, porque "todos habían luchado por la independencia" (Anderson, 2005: 333-336). En el futuro abierto por la independencia no había cabida para juzgar los crímenes cometidos en el pasado: se ignoró la situación casi de guerra civil entre Kikuyus (según estimaciones de Anderson los británicos contaban con unos 60.000 colaboradores, que serían el blanco favorito de las guerrillas Mau Mau) y los crímenes cometidos por la administración colonial. Conforme los acuerdos de independencia, el Mau Mau continua siendo ilegal.

No hubo investigaciones en la presidencia de Kenyatta, como tampoco las hubo en Inglaterra, donde la independencia de la antigua colonia contribuyó a que se perdiera el interés por hacer público el régimen de terror que la administración imperial había establecido en los últimos años.

Pero la polarización entre amnesia y memoria dejó desasistidos a quienes habían sufrido las injusticias en el pasado, fuesen o no miembros de la rebelión. Como en tantos otros casos, esa "memoria llena de agujeros", para utilizar la elocuente expresión de Dan Stoner (Stoner 2013: 110) llevaría a algunos de ellos a constituir comunidades de la memoria (Todorov), con una doble misión: que el mundo se entere de lo ocurrido y conseguir reparaciones en los tribunales.

Hace tan solo unos meses, en Junio de 2013, tras cuatro años de batallas legales, tres supervivientes $^{21}$, Paulo Muoka Nzili de 85 años, Wambugu Wa Nyingi de 84 y Jane Muthoni Mara de 73 consiguieron que un tribunal británico admitiese su querella y juzgase los "innombrables actos de brutalidad" cometidos contra ellos: a Paulo Nzili le había castrado un oficial británico con unas tenazas de las que se usan para el ganado; Wambugu Nyingi estuvo a punto de morir apaleado en la terrible masacre del campo de Hola. Por su parte, Jane Mara, una adolescente de 15 años sufrió heridas terribles cuando le introdujeron por la vagina una botella de cristal caliente. Como muchas otras personas, durante décadas vivieron con las secuelas físicas y síquicas de sus torturas hasta que, con el apoyo de la Comisión de Derechos Humanos de Kenia y el de personas individuales como Desmond Tutu o Graça Machel lograron que un tribunal británico admitiese la querella. Previamente hubo de pronunciarse competente para juzgar las torturas y que las numerosas pruebas existentes $-y$ las que aparecieron en los archivos secretos- permitirían un juicio justo a pesar de los años transcurridos.

Tras la sentencia favorable a los demandantes, en junio de 2013, Willliam Hague, ministro de Asuntos Exteriores británico comunicó al Parlamento que tras el veredicto con que concluía el largo proceso judicial, el Gobierno había aceptado pagar unas 2600 libras a unos 5000 supervivientes de los campos de prisioneros que las autoridades británicas habían

21. Una cuarta demandante, Susan Ciong’ombe Ngondi, había fallecido dos años antes a los 71 años. 
establecido en Kenia, así como mostraba su arrepentimiento por las torturas sufridas por miles de personas encarceladas durante la rebelión Mau Mau. Según estimaciones anteriores al descubrimiento de los nuevos archivos murieron unas 90.000 personas, la mayoría Kikuyu y más de 100.000 estuvieron recluidos en una compleja red de campos y subcampos de concentración. Muchas mujeres sufrieron torturas y violaciones sexuales durante los interrogatorios a los que eran sometidas en las propias aldeas convertidas, como el resto del país Kikuyu en una inmensa prisión. 


\section{REFERENCIAS BIBLIOGRÁFICAS}

Anderson, David (2005a) Histories of the Hanged. The Dirty War in Kenya and the End of Empire. New York and London: Norton.

Anderson, David (2005b) Burying the Bones of the Past. History Today, Vol. 55, Iss 2 Cobain, Ian (2012-2013) Serie de artículos sobre el juicio y el Mau Mau. The Guardian Cooper, F. (2005) Colonialism in Question. Berkeley: University of California Press Das, Veena (2008) "Violence, Gender, and Subjectivity". Annual Review of Anthropology. 37. pp. 283-299

Elkins, Caroline (2005) Imperial Reckoning. The Untold Story of Britain's Gulag in Kenia. New York: Owl Books, Henry Holt and Company.

Frigolé, Joan (2003) Cultura y Genocidio. Barcelona: Universitat de Barcelona.

Kleimman, A., Das V. y Lock, M. (1997) Social Suffering. Berkeley: University of California Press.

Mamdani, M. (2002) When Victims Become Killers. Princeton: Princeton U.P.

Mamdani, M. (1996) Citizen and Subject. Contemporary Africa and the legacy of late colonialism. New Jersey: Princeton University Press.

Mann, M. (2009) El lado oscuro de la democracia. Valencia: PUV

Moreno Feliu, Paz. (2010ª) En el corazón de la zona gris. Una lectura etnográfica de los campos de Auschwitz. Madrid: Trotta.

Moreno Feliu, Paz. (2010b) Encrucijadas Antropológicas. Madrid: Editorial Universitaria Ramón Areces.

Murray, Jocelyn (1976) The Church Missionary Society and the "Female Circumcision" issue in Kenya: 1929-1932. Journal of Religion in Africa. Vol 8. p. 2.

Olick, F y Robbins, J (1998) Social Memory Studies: From "Collective Memory" to the Historical Sociology of Mnemonic Practices. Annual Review of Sociology, 24. pp. 105140.

Shaw, Carolyn M. (1994) Colonial Inscriptions: Race, Sex and Class in Kenya. Minneapolis: University of Minnesota Press.

Stone, D. (2013) "Genocide and Memory". En D. Bloxham y A.D. Mosses (eds) The Oxford Handbook of Genocide Studies. Oxford: Oxford U.P.

Mamoulaki, Elena (2012) An unexpected hospitality: narratives, practices and materialities of the memory of exile and cohabitation on the island of Ikaria. Tesis doctoral: Universitat de Barcelona.

Vernant, J-P. (2008) Atravesar fronteras. Entre mito y política II. México: F.C.E.

White, Luise. (1990) The Conforts of Home. Prostitution in Colonial Nairobi. Chicago: Chicago University Press.

White, Luise. (1990b) "Separating the Men From the Boys: Constructions of Gender, Sexuality and Terrorism in Central Kenya, 1939-1959”. The International Journal of 
African Historical Studies, Vol 23, No 1. pp.1-25.

Wilson, H.S. (1977) The Imperial Experience in Subsaharan Africa Since 1870. Minneapolis:

University of Minnesota Press.

Wolf, Eric (1979) Las luchas campesinas del siglo XX. México: Siglo XXI

Yates, F. (1974) El arte de la memoria. Madrid: Taurus. 